\title{
Pojam žalovanja kod Rolanda Barthesa i Jacquesa Derride
}

Matej Vidaković*

matej.0211@gmail.com
UDK: 159.942.3:393

1 Barthes, R.

1 Derrida, J.

Pregledni članak / Review

Primljeno: 9. prosinca 2015.

Prihvaćeno: 18. veljače 2016.

Ovaj članak prikazuje pojam žalovanja kako je on prisutan u djelu »Dnevnik korote "Rolanda Barthesa i u tekstu Jacquesa Derride »Ovnovi. Neprekinuti dijalog: između dvije vječnosti, pjesma«. Derridin tekst je baziran na predavanju održanom kao posmrtni govor upućen Derridinom prijatelju, filozofu HansuGeorgu Gadameru. Misli iznesene u tom tekstu, u ovom su članku uklopljene u širu sliku Derridinih promišljanja o gubitku i smrti, budući da su to neke od tema kojima se stalno vraćao u svom radu. Jedan od ciljeva iznošenja ovoga proširenog pogleda jest predstavljanje tog pomalo zanemarenog područja unutar Barthesova i Derridina djelovanja na način na koji je naznačeno u primarnim tekstovima. Drugi cilj je skretanje pozornosti na sljedeću tezu: Derrida i Barthes dvije su strane iste medalje - dvije različite struje u razmišljanju o gubitku, koroti i neponovljivosti iskustva Drugoga, a koje se međusobno nadopunjuju $i$ mogu se podvesti pod dva arhetipa: sizifovski i atlantski.

Ključne riječi: žalovanje, gubitak, smrt, Drugi, sizifovski i atlantski arhetip.

\footnotetext{
* Matej Vidaković, student filozofije i religijskih znanosti na Fakultetu filozofije i religijskih znanosti Sveučilišta u Zagrebu, Jordanovac 110, pp 169, HR-10001 Zagreb.
} 


\section{Uvod: naznačavanje polazišnih točaka i smještanje u kontekst}

Roland Barthes i Jacques Derrida, dvojica suvremenika i dvije svojevrsne institucije »postmodernog stanja « u kontinentalnoj misli, dijelili su, pored sličnih preokupacija u svojem misaonom radu, i jednu specifičnu temu, koja pomalo odudara od standardnog svjetla pod kojima smo najčešće naviknuti promatrati bilo Barthesa, bilo Derridu. Obojica su, naime, unutar svojih bogatih i raznolikih opusa posvetili pažnju jednoj vrlo specifičnoj pojavi - žalovanju. Žalovanjem, gubitkom i korotom bavio se Barthes u nizu svojih bilješki koje su objelodanjene pod nazivom $»$ Dnevnik korote $«,{ }^{1}$ a nastale su pod izravnim utjecajem majčine smrti, dok je Derrida za života napisao impozantnu zbirku posmrtnih govora, eseja o preminulim prijateljima i drugih iskaza sućuti i poštovanja, a koji su objedinjeni u knjizi »The Work of Mourning «. ${ }^{2}$

Pokušat ćemo ovdje ponuditi interpretaciju pojma žalovanja temeljenu na Barthesovu »Dnevniku korote«, te na Derridinoj znamenitoj »heidelberškoj eulogiji«, odnosno posmrtnom govoru kojeg je Derrida održao na Sveučilištu u Heidelbergu 15. veljače 2003. u čast preminulom prijatelju Hansu-Georgu Gadameru (1900-2002). Pri tom će se nastojati sugerirati da »Dnevnik korote« $\mathrm{s}$ jedne strane, te Derridini »Ovnovi $\aleph^{3} \mathrm{~s}$ druge strane, predstavljaju dvije strane jedne medalje; veliku i univerzalnu misao o prirodi žalovanja, boli prouzročenoj gubitkom te postavljanju konkretnoga Ja pred tom općeljudskom stvarnošću.

Valja ipak, odmah na početku naznačiti neke posebnosti koje se moraju uzeti u obzir radi same objektivnosti promatranja odabranih tekstova. Barthesovo se djelo nesumnjivo razlikuje od Derridina već i po subjektivnim razlozima utkanima u njegov neposredni nastanak. Dok Derrida svoje "posmrtno slovo« drži zagledan u uspomenu na svojeg prijatelja i znanca, reflektirajući o njemu doduše s poštovanjem i divljenjem dostojnima najčistijeg prijateljstva, Barthesov je gubitak posve drukčije prirode. Barthes svoje bilješke, koje piše na cedulje pohranjivane u pisaćem stolu, a koje će kasnije biti objavljene kao »Dnevnik korote«, započinje dan nakon smrti svoje majke. Neusporediva je emocionalna bliskost autora s preminulom osobom možda i najvažniji element koji veoma razlikuje Barthesove misli o majci, od Derridinog govora, održanog više od dva desetljeća nakon nastanka »Dnevnika korote«, kao svojevrsnog, simboličnog rekvijema Gadameru. ${ }^{4}$

\footnotetext{
${ }^{1}$ Roland BARTHES, Dnevnik korote. 26. listopada 1977. - 15. rujna 1979., tekst priredila i bilješkama popratila Nathalie Léger, s fran. prev. Morana Čale (Journal de deuil), Zagreb, 2013.

2 Jacques DERRIDA, The Work of Mourning, ur. Pascale-Anne Brault, Michael Naas, Chicago, 2001, http://monoskop.org/images/6/65/Derrida_Jacques_The_Work_of_Mourning_2001.pdf; fran. verzija: Chaque fois unique, la fin du Monde, Pariz, 2003.

${ }^{3}$ Jacques DERRIDA, Ovnovi. Neprekinuti dijalog. Između dvije vječnosti, pjesma, uredio i pogovorom popratio Danijel Miščin, prev. Lukrecija Kireta (Bé liers. Le dialogue ininterrompu: entre deux infinis, le poè me, Pariz, 2003), Zagreb, 2014.

${ }^{4}$ Posljednji datirani ulomak iz »Dnevnika korote« zabilježen je 15. rujna 1979., dok je Derrida
} 
Isto tako, valja se othrvati ozbiljnoj napasti, posebice kad je Barthesovo djelo u pitanju. Dok priroda predavanja, odnosno usmenog izlaganja, u kombinaciji s ipak postojećom »distancom « koju Derrida može imati spram Gadamera kao onoga koga je izgubio, ostavlja problematiku interpretacije uglavnom na površini, Barthesov je tekst, već zbog pisanog oblika u kojem se predočuje čitatelju, te njegove isprekidane, gotovo aforističke forme sjajan mamac za nevjerojatne mogućnosti kritičkog čitanja u tradiciji koju je pomogao uspostaviti upravo Barthes. Nesumnjivo se teško oteti želji da se pristupi pažljivom raščlanjivanju tih korotničkih bilješki, autora koji je ionako proklamirao stajalište o »jeziku kao onom mediju kojim se autor izražava i koji (jezik) sadrži vlastita pravila te autoru određuje način uporabe.$^{5}$ Nesumnjivo, zna li se što je Barthes načelno držao o jeziku, te o pojmovima »autora « $\mathrm{i} » d j e l a «$, gotovo da nas sama činjenica njegova autorstva nad »Dnevnikom korote« tjera da i taj tekst podvrgnemo strogoj strukturalističkoj analizi. Unatoč tomu što za takav postupak posve sigurno postoji prostran i još uvijek nedovoljno istražen teritorij, ovdje se neće krenuti tim smjerom. Umjesto ustrajavanja na strukturalističkom diskursu, zastupat će se, naime, tvrdnja da »Dnevnik korote« valja ipak promatrati kao djelo u kojemu subjektivni element ipak bitno preteže nad onim objektivnim. Bitno je zaista istaknuti da Barthesovo djelo nije zaokružena struktura, dovršena knjiga, već »hipoteza o knjizi koju je želio, koja pridonosi razradi njegova djela i u tome ga smislu rasvjetljuje ${ }^{6}{ }^{6}$

No, isto tako, za posvemašnje razumijevanje i Derride i Barthesa, posebice u kontekstu žalovanja na koje se ovdje usredotočuje, ipak je važno ne ispustiti iz vida duhovno ozračje u kojem oni stoje. To su ljudi »postmodernog stanja«, $\mathrm{s}$ točno određenim mjestom unutar misaone tradicije kojoj i sami pripadaju i, iako taj element, kao što je istaknuto, ne bi trebao prevladati nad njihovim bavljenjem univerzalnom temom kakva je žalovanje i njegova priroda, način manifestacije, nikako ne bi bilo u skladu s našim interesima zanemariti značajke koje donekle oblikuju njihovu misao i duhovnu strukturu.

Ono, pak, zbog čega je potencijalno važno promatrati misli dvojice filozofa o gubitku i onome što neizostavno gubitak prati - žalovanju, jest činjenica da u tome obojica koračaju područjem dijaloške filozofije, filozofije suprotstavljanja svojega $»$ a $«$ i onoga $»$ Drugog $«$, onoga buberovskoga $» T i \ll$. Iako se Derrida i ranije kretao u sličnim sferama, barem kad je u pitanju njegova etika, »Ovnovi« će u tom nizu stajati poput simbolične summe, istaknute krune gotovo cjeloživotne refleksije. Međutim, ono što će nam teško promaknuti jest da misao o iskustvu umiranja, tom iskustvu koje »nije prosvjetljenje, niti stjecanje nove spoznaje: već je ono izravno otkriće nepoznate dubine, nepoznavanje koje nas je izlagalo

svoju znamenitu eulogiju održao 15. veljače 2003.

${ }^{5}$ Usp. Miroslav BEKER, Suvremene književne teorije, Zagreb, 1999, 44.

${ }^{6}$ Nathalie LÉGER, Uvod, u: Barthes, Dnevnik korote..., 6-7, 7. 
svakojakim zabludama i razočarenjima «, ${ }^{7}$ ono čini krajnju granicu do koje dijaloška filozofija može ići. Posljednju nepoznanicu na koju možemo usmjeriti žarku svjetlost svoje misli.

Razmišljajući o paradigmama zapadnjačkog poimanja smrti, koje ćemo unutar okvira ovog teksta uzeti kao relevantno, posebice je zanimljivo vidjeti što je o tome zapisao francuski povjesničar Philippe Aries koji se inače posebnim žarom bavio zapadnim poimanjem smrti kroz povijest. Tako on kaže da su

"promjene čovjekova stava prema smrti veoma spore ili situirane u duge vremenske periode u kojima se ništa ne događa, te ih zbog smanjenog kapaciteta kolektivne memorije suvremenici ne percipiraju . $^{8}$

Trudeći se pojmiti širu sliku, čini se da je najveća promjena u zapadnom shvaćanju smrti nastupila s prijelazom srednjega vijeka u renesansu, odnosno humanizam. Srednjovjekovni se čovjek »u smrti podčinjavao jednom od velikih zakona vrste i nije ni pomišljao da mu umakne, kao što se nije niti opterećivao njime «. ${ }^{9}$ Međutim, kako je to oštroumno primijetio Aries, slika se počinje mijenjati kad $» u$ ogledalu svoje osobne smrti svaki čovjek iznova otkriva tajnu svoje individualnosti $\omega^{10} \mathrm{Smrt} \mathrm{u}$ tom trenutku prelazi iz sfere kolektivnoga $\mathrm{u}$ sferu osobnoga. Kao takva, ona se povezuje s pojmom neuspjeha. Čitav se život sa svojim dotadašnjim vrhuncima, malenim pobjedama i radostima doima posve promašenim projektom - upravo zato što se nije uspio oteti ledenom stisku smrti koji označava kraj. Vidljivo je to i u izmještanju umirućega iz same ceremonije smrti. Upravo je »Ja«, ono koje leži na samrtničkoj postelji, bilo ono koje rukovodi svojim posljednjim zemaljskim trenutcima, okupljajući oko sebe zajednicu, simbolički tako završavajući projekt svojeg vlastitog života. Međutim, smrt je iz okružja doma prognana u bolnice, a mjesto umirućega preuzeli su oni koji nadživljavaju. Smrt je ustvari tragedija koja se događa nadživjelome, a ne onome koji umire. Ona je skandalozna, grozna, tabu tema o kojoj se eventualno ponekad šapće, a i to s neugodnim osjećajem u ustima i ledenim trncima u srcu.

Sve spone koje je čovjek nekada još imao s nebom, koje su se u najgorem slučaju mogle temeljiti barem na ostatcima autoriteta koji je u narodu uživala Crkva - danas su popucali. Stupovi neba ne tresu se - oni su uz tresak već pali. Sve svetinje i komadići utjehe za koje bi se čovjek, tumarajući današnjim svijetom, mogao uhvatiti poprilično su klimave, doimlju se više nego ikada pribježištima koja bira prije ludost, nego razbor, te odražavaju ponajprije čovjekov zaborav o tome tko je on sam, zbog čega više oko sebe i u sebi ne nalazi ništa osim cinizma i sumnje.

\footnotetext{
7 Vladimir JANKELEVITCH, Smrt, Zagreb, 2011, 22.

${ }^{8}$ Filip ARIJES, Eseji o istoriji smrti na Zapadu, s fan. prev. Zorica Banjac (Philippe Aries, Essais sur l'histoire de la mort en occident, du moyen à nos jours, Seuil, 1975) Beograd, 1989, 15.

${ }^{9}$ Isto, 36.

${ }^{10}$ Isto, 50 .
} 
Možda je upravo u tom cinizmu i nepovjerljivosti razlog što je danas o smrti možda teže govoriti nego ikada, iako smo se u njezinu razumijevanju puno pomakli u zadnjih dvije i pol tisuće godina. S fiziološke, odnosno biološke strane, smrt danas možemo savršeno opisati. No, razmišljajući o njoj još uvijek smo osuđeni na iste riječi: gubitak, tuga, očaj, napuštenost, strah, suze, korota... Njeno nam je »lice« još uvijek nedohvatljivo. Jedan od ponajboljih kompendija tog suvremenog, »skandaloznog « curiosuma smrti, posve sigurno je i već spomenuta studija Vladimira Jankelevitcha, kratkoga i znakovitog naslova - Smrt«. Istovremeno neke od Jankelevitchevih tvrdnji i često meditativno-liričnih misli savršeno oslikavaju crtu kojoj nesumnjivo pripada i Barthesov »Dnevnik korote « u svoj svojoj fragmentiranosti, a posve sigurno i Derridina eulogija.

Ako želimo govoriti o shvaćanju smrti, piše Jankelevitch, i ako je želimo učiniti predmetom filozofskog promišljanja, moramo je prvo shvatiti. Shvatiti je kao jednu od neposrednih zadanosti ovoga života, čak dapače, kao krajnju njegovu točku, njegovu posljednju stanicu. Međutim, što zbog uronjenosti u vrijeme, što zbog osobnog heroizma koji se najbolje manifestira u vlastitu uvjerenju da su, osim mene, svi drugi smrtni, za nas »shvatiti smrt jest uvijek osjećati se osobno pogođenim tom prijetnjom «. ${ }^{11}$ Iz toga proizlazi da k stvarnosti smrti i sigurnosti činjenice da ćemo i mi umrijeti prilazimo tek kroz gubitak bliske osobe. Bol i praznina koje ostavlja njihov odlazak često se kose s našim shvaćanjem prema kojemu pod nekakvim staklenim zvonom našeg osobnog egoizma nema mjesta smrti za nas i za one koje volimo. Mi, zajedno s našim dragima, moramo biti pošteđeni tog krajnjeg užasa hladnoće i raspadanja, jer u suprotnom čitava ova igra koju nazivamo životom nije ništa drugo nego opasna farsa. Odnosno, kako bi rekao Jankelevitch, smrt dragog nam bića

»na stanovit način jest zapravo naša vlastita smrt, budući da neutješan čovjek tu oplakuje nenadomjestivo ${ }^{12}{ }^{12}$

Drugim riječima, predmet žaljenja smo istovremeno i mi sami, kao i Drugi $^{13}$ sa svom svojom neponovljivošću, originalnošću i jedinstvenošću koja je iz njega isijavala i davala nam da ga možemo prepoznati i uopće nazivati Drugim. Međutim,

»onaj koji umire umrijet će sam, sam suočen sa osobnom smrću kojom svatko za sebe mora umrijeti, sam čini samotnički korak, što ga nitko umjesto nas ne može napraviti, i koji će svatko, kad nastupi taj čas napraviti za sebe sama kao pojedinac ${ }^{14}{ }^{14}$

\footnotetext{
${ }^{11}$ Jankelevitch, nav. dj., 29.

${ }^{12}$ Isto, 39.

${ }^{13}$ Valja naglasiti kako se »Drugi« velikim početnim slovom, ovdje ne piše u kontekstu personalističke filozofije koja na taj način ponekad referira na Boga, već veliko početno slovo ispred riječi »Drugi« ovdje stoje iz puke levinasovske dosljednosti autora, a koja upućuje na »čistoću « i »neponovljivost« Lica Drugoga.

${ }^{14}$ Jankelevitch, nav. dj., 38.
} 
Upravo je stoga žalovanje uvijek žalovanje za Drugim, dok »moja, osobna smrt« u smislu iskustva - ne postoji.

$\mathrm{U}$ trenutku vlastite smrti, ne ostaje vremena za filozofsku refleksiju. $\mathrm{Ne}$ ostaje vremena da se dovikne onima koje polako ostavljamo za sobom vidimo li u daljini možda svjetlost tisuća svjetala ili pak samo neprobojnu tamu. O smrti se, dakle, može misliti samo promatrajući smrt drugoga. I koliko god oplakivali drugoga, koliko nas god njegov odlazak pogodio, kronični nedostatak svakog premišljanja o tom istom odlasku jest taj što nešto takvo nismo nikada iskusili na sebi. Mi nemamo »iskustvo« odlaska. Konačnog odlaska. Najbliže što bismo se tome mogli primaknuti jest eventualna tjeskoba pred spoznajom vlastite smrtnosti, a teško se oteti dojmu da je u pitanju samo blijeda sjena samrtničkog očaja, te izbezumljenosti koja proizlazi iz hitnosti smrti, odnosno iz njezine neizbježnosti. ${ }^{15} \mathrm{~Pa}$ ipak, to nikako ne sprječava čovjeka da se i dalje pita o smrti na filozofski način ili pak da u religiji traži svoje odgovore; ovisno o pojedincu.

Stoga je glavna teza ovoga rada da Barthes i Derrida, svaki za sebe, čine dva, jungovski rečeno, arhetipa žalobnika (odnosno žalovatelja), arhetipa koji su donekle svojstveni svakome od nas u različitoj mjeri, ovisno o karakteru ili situaciji, te koji predstavljaju dva stajališta koja čovjek može zauzeti pred smrću, gubitkom drage osobe, prestankom dijaloga s Drugim nakon kojeg ostaje samo nenadomjestiva praznina. Dakako da se time iskustvo gubitka nipošto ne želi uopćavati, niti generalizirati, već je ovo samo pokušaj da se ukratko prikaže svojevrsna morfologija žalovanja, a koju su Derrida i Barthes svaki na svoj način artikulirali velikom smjernošću, ljudskom toplinom i, ako se tako može reći, ljubavlju.

Barthesovoj koroti tako ćemo pridati predznak - »sizifovska«, koji će se odnositi na svijest o nenadomjestivosti gubitka te na svesrdne pokušaje povratka svakodnevnim životnim ritualima koji se često urušavaju pred uvijek iznova pronađenom svijesti o gubitku koji je toliko subjektivno velik da prožima sve aspekte nečijeg života. S druge strane, derridijansku koncepciju žalovanja može se nazvati »atlasovskom«. Sjetimo li se znamenitog Titana iz grčke mitologije, postat će jasno kako ona u bitnome počiva na skupljanju snage za podnošenje gubitka. I to naglašeno, podnošenje, ali ne i mirenje s gubitkom. Jer, slikovito rečeno, svojim mislima i stavom koji zauzima prema smrti i odlasku Drugoga, Derrida svojevoljno na svoja pleća preuzima ulogu Atlanta koji pridržava sama nebesa svijeta koji su nastanjivali on i Drugi; on se pokazuje kao čuvar i nastavljač tog istog svijeta koji još jedino u njemu može nastaviti svoje postojanje, te je takva, uistinu pomalo antičko-tragička perspektiva u njega vrlo bliska činu nekih davno zaboravljenih oblika herojstva.

${ }^{15}$ Usp. isto, 28. 


\section{Roland Barthes $i$ žalovanje u »Dnevniku korote«}

Početak Barthesovih bilješki nesumnjivo odražava iznenadnost smrti kojom je bio pogođen. Smrt, kao ono što se stalno iščekuje u nekoj neodređenoj svijesti da ipak nikada neće doći i odnijeti nas ili nekoga nama dragoga, jedna je od tragedija suvremenog čovjeka. Prvi se zapisi stoga kreću u rasponu od vlastite svijesti o stupanju u korotu, po svojoj obrednoj važnosti u Barthesovim mislima smještenoj odmah do prve bračne noći, opservacija o konkretnim činjenicama u svijetu (poput odvoženja smeća), te postavljanja pitanja samome sebi o tzv. »budućo-maniji«, odnosno zamjenjivanju pokojnikovih stvari novima, kojima tako i simbolično istiskujemo sjećanje na preminuloga. ${ }^{16}$ Međutim, dojam koji prevladava je opća izgubljenost. Iako Barthes uspijeva bilježiti sitnicu poput odvoženja smeća i povezati je sa sjećanjem na majčinu bolest i spoznaju da je upravo kamion za smeće označavao kraj noći i kraj izolacije koju je u svojstvu bolesnika tada njegova majka proživljavala, razvidno je da su takve sitnice izbile u prvi plan zbog toga što konkretno suočavanje s gubitkom ipak mora doći nakon nekog vremena. Žal, osjećaj gubitka - mora se postupno artikulirati, a Barthes to još nije u stanju.

Prve naznake te sposobnosti, međutim, ubrzo se pojavljuju u sljedećim riječima:

»(...) korota (potištenost) je drukčija nego bolest. Od čega bi se htjelo da ozdravim? U kakvo stanje da dospijem, u koji život? « ${ }^{17}$

Upravo se ovdje počinje polako ocrtavati sve neumoljiviji jaz između neshvatljivosti, nelogičnosti osuđenosti na gubitak, današnjem čovjeku tako bolno nerazumljive i neuklopljive $u$ njegov način života. Oko te osobne tragedije svake individue Derrida će tkati srž svojeg razmatranja potaknutog Gadamerovim odlaskom, no time ćemo se pozabaviti kasnije. Kao odraz ovoga, Barthes malo kasnije bilježi:

»Besmrtnost. Nikad nisam shvatio taj čudnovati skeptički stav: ne znam. «18

Ovo je možda najbolji primjer onoga što je nazvano "postmodernim stanjem« kojemu i Barthes pripada. Besmrtnost je jedan od mitova koje je suvremenost pokušala nadići u njihovu temeljnom religijskom značenju i kontekstu; ona je danas samo gorki cinizam kojim se može tješiti preživjeli koji stoji uz tijelo pokojnika. Pa ipak, pred neumoljivim: Nikad više!, koje poput Poeova gavrana izgovara Smrt, pred tom radikalnom negacijom života do koje dolazi neovisno o našoj volji, htijenju ili izboru, besmrtnost se uvijek iznova vraća

\footnotetext{
${ }^{16}$ Usp. Barthes, Dnevnik korote..., 11-15.

${ }^{17}$ Isto, 16.

${ }^{18}$ Isto, 17.
} 
kao jedan od valova metafizičkog oceana koji nas zapljuskuje kad se nađemo suočeni s osjećajem praznine koja nastaje odlaskom Drugoga.

Sljedeći nužan zaključak jest svijest o vlastitoj smrtnosti koji nužno mora proizaći iz osuđenosti da gledamo i svjedočimo kraju svijeta jednoga Ti koje nam je bilo toliko blisko i s kojim smo imali odnos koji smo držali točno onoliko transcendentnim da ga uopće nismo uzimali u kategorijama vremena ili prolaznosti, niti ne pomišljajući da će on jednoga dana morati okončati. U zapisu od 27. listopada 1977., Barthes tako bilježi:

»Po prvi put u posljednja dva dana iskrsava prihvatljiva (istaknuto u izvorniku) pomisao da ću i ja umrijeti. « ${ }^{19}$

Međutim, što se to čini prihvatljivim u misli o vlastitoj smrti? Njezina neumitnost? Ili se pak radi o subjektivnom izrazu boli koji se dade prevesti u spoznaju da je kraj jednog odnosa na neki način označio i kraj jednog života koji je dotada postojao? Barthes zapisuje dalje:

»U koroti sam za odnosom s osobom koju sam volio... Na to me potiču riječi (ljubavi) koje mi iskrsnu u glavi... «20

Znakovito je da Barthes neće napisati da je u koroti za konkretnom osobom (majkom), već za »odnosom «s konkretnom osobom. Iako bismo ovdje mogli tražiti čvrste argumente u prilog, primjerice, Buberovoj filozofiji dijaloga, čini se da čak nije niti potrebno ići daleko. Ja se ostvarujem tek u odnosu spram drugoga, moje biti, uvijek je i svakako biti-u-odnosu-spram-tebe, odnosno u odnosu prema Drugome. Ostvarivanje nužno uključuje i potvrđivanje mojega »ja«, kao i njegovo obogaćivanje, a ovaj se proces odvija recipročno. Još jedna poprilično znakovita potvrda iznesenog stiže u zapisu od 5. studenog 1977. godine:

»U slastičarnici (tek toliko) kupujem čokoladni tartuf. Dok poslužuje stranku, djevojka kaže: Evo. Tu sam riječ izgovarao kad bih nešto donio mami dok sam je njegovao. Jednom je, pri kraju, polusvjesno kao jeka ponovila: Evo (Tu sam, što smo cijeli život govorili jedno drugome). Riječ koju je djevojka izgovorila natjerala mi je suze na oči. $^{21}$

Dok se ovdje čini da puko sjećanje Barthesa tjera na suze, ovaj posve subjektivan zapis pruža nevjerojatno suptilnu, ali snažnu elaboraciju misli da je svijet nešto poput čarobnog zrcala u kojemu smo mi sposobni prepoznavati odraz Drugoga, a ne samo i/li jedino svoj odraz. Ne sjećanje na konkretan moment u kontekstu majčine osobe kao cjeline, već upravo njezina cjelovitost ono je što Barthesa u tom trenutku potresa.

\footnotetext{
${ }^{19}$ Isto.

${ }^{20}$ Isto, 47.

${ }^{21}$ Isto, 45 .
} 
Stadij koji slijedi okarakteriziran je još dvama elementima i on na koncu i zaokružuje sliku Barthesova žalovanja. Prvi je, naime, žeđ za dijalogom i nemogućnost njegova ostvarivanja, a drugi je svijest o »sizifovskoj« prirodi vlastite korote. Pitanje dijaloga naznačeno je tako u bilješci od 12. studenoga 1977. godine:

»Danas - na svoj rođendan - bolestan sam, a ne mogu - nema potrebe da joj to kažem. ${ }^{22}$

Jasno je da ovdje nije riječ o potrebi da se nešto kaže samo kako bi postojala svijest o rečenome, već želja da se s nekim komunicira, da mu se prenese konkretno osobno iskustvo, da se dobije povratna informacija, popraćena u ovom specifičnom slučaju i majčinskom brigom i nježnošću. I opet - nužno slijedi udar o zid Tišine. Smrt, ta radikalna točka, ta posvemašnja šutnja, ne haje previše za naše želje. Po strukturi i tendenciji veoma sličan zapis ponavlja se i 12 . veljače 1978. godine:

»Snijeg, mnogo snijega po Parizu; to je čudno. Kažem sebi i zbog toga patim: nje više nikad neće biti da ga vidi, da joj ga ispripovijedam. « $^{23}$

Izuzev čežnje za dijalogom, za "pripovijedanjem o snijegu«, ovdje se pojavljuje još jedna dimenzija, a to je želja da se konkretno iskustvo (snijega u Parizu) priopći, da se u tom trenutku sudjeluje uz Drugoga, da se trenutak obuhvati prisustvom Drugoga koji više nije ovdje, što nužno upućuje i na čežnju za fizičkom prisutnošću. Stvari se mogu izreći, »ispripovijedati«, ali se stvari mogu i neposredno iskusiti, doživjeti u najelementarnijem, fizičkom smislu. Korota nipošto nije samo čežnja za osobinama Drugoga, uobličenima u njegovim izrečenim mislima koje se smatraju temeljem dijaloga, već i za fizičkom prisutnošću pred kojom i riječi ponekad mogu postati nedovoljne i nemoćne.

Posljednje na što valja ukazati kad je Barthes u pitanju jest samosvijest o »sizifovskoj « prirodi vlastite korote. Dok spoznaja o vlastitoj smrtnosti koja proizlazi iz smrti Drugoga, odnosno bliskog Drugoga, i kraja svijeta koji je bio su-kreiran s tim Drugim, biva posve logičnom, ona se postupno prelijeva i na spoznaju o konačnoj smrtnosti i svih drugih ljudi koju okružuju moje Ja i razvaline svijeta čiji sam ja »brodolomac« u stvarnosti. Barthes uviđa da mu žalost nije oduzela ništa, ali se zauzvrat i ne troši. Osjeća da upravo u svakom trenutku žalosti po prvi puta proživljava vlastitu korotu. ${ }^{24}$ Vrijeme nije liječnik ni saveznik, vrijeme se pretvara u krvnika, a Barthes postaje njegovim taocem. Znanje o smrti iz »druge ruke«, ustupa mjesto osobnom znanju praćenom subjektivnim doživljajem.

Jedna od osobina ljudske egzistencije, strahovati za drugoga, u kojoj se strahovanje pojavljuje kao izraz brige i vezanosti, postaje posve bespredmetna $\mathrm{u}$

\footnotetext{
${ }^{22}$ Isto, 54.

${ }^{23}$ Isto, 101.

${ }^{24}$ Usp. isto, 79 i 83.
} 
situaciji kada osoba biva lišena onoga za koga bi mogla strahovati. Posebno je zanimljivo istaknuti to Barthesovo stajalište, budući da će Derrida imati posve suprotno mišljenje. U njega nema predaje vremenitosti melankolije, žala i utapanja u porazu tog istog vremena. Dijalog se neprekidno nastavlja, Drugoga nosim u sebi i sa sobom, a istovremeno u sebi nastavljam i naš dijalog čije je glavno obilježje možda upravo kontinuitet. Govoreći o vremenu dok mu je majka bila živa, Barthes ga opisuje kao »cijeli moj prošli život« ${ }^{25}$ Upravo to stanje, figurativno rečeno, »izgubljene nevinosti« jest zastrašujuće u svojoj definitivnosti. Natrag nema, ostaju samo usporedbe i svijest o tome da se jedno razdoblje, »cijeli jedan život«, privelo kraju. Stvarnost i svakodnevica konstantno na to podsjećaju. Krivnja preživjeloga ${ }^{26}$ je tu i ona razdire, to i Barthes shvaća kada kaže: »Počinjati iznova, bez odmora. Sizif.. ${ }^{27}$

U maniri, dakle, Camusova Sizifa, koji neprestano pun prkosa pred licem Besmisla uvijek iznova kotrlja kamen uz brdo, i Barthesova korota se nalazi pred zidom. Žedan dijaloga, ali u nemogućnosti njegova ostvarivanja; mučen teretom nadživjelosti koji implicira popudbinu sjećanja na čitav jedan svijet, život s njegovim specifičnostima, rastrgan - to je Barthesova pozicija i to je istovremeno i tragedija ljudskoga gubitka i žalovanja koje slijedi nakon njega. Riječ koja bi povezala ovo sada s onim što je bilo, ostaje nam nepoznata. Nikad nećemo u potpunosti moći izreći svoj gubitak, niti smrt pretvoriti u dijalog u onom smislu kako ga se poima u svakodnevnom životu. Ili, kako je to na kraju svojeg romana »Lord Jim«, kroz usta Marlowea, izgovorio Joseph Conrad:

»Nisu li naši životi prekratki da bi nam dopustili da do kraja izreknemo ono što nastoji izreći neumorno naše mucanje? Odustao sam od toga da čujem tu zadnju riječ čiji zvuk bi potresao i zemlju i nebo, samo kad bismo je mogli izgovoriti.« ${ }^{28}$

\section{Derrida i misao o smrti u kontekstu njegova korotničkog opusa}

Kod Barthesa majčina smrt postaje conditio sine qua non razmišljanja o smrti. Nesumnjivo bi bilo zanimljivo zadržati se na Barthesovim promišljanjima o tom fenomenu koja postoje i u drugim njegovim djelima, ali za to ovdje

\footnotetext{
${ }^{25}$ Isto, 137.

${ }^{26}$ Valja naglasiti da se ovdje termin »krivnja preživjeloga« ne koristi u smislu koji se ustalio u kulturi kad se govori o konkretnim osobama koje su preživjele iskustvo Holokausta. Taj pojam igra važnu ulogu u razumijevanju suvremenih povijesno-kulturoloških implikacija, a ovdje se rabi u odnosu na osobu koja je doživjela smrt Drugoga i postala »ona koja je nadživjela«.

${ }^{27}$ Barthes, Dnevnik korote..., 147 (zapis je od 11. lipnja 1978.).

${ }^{28}$ Prijevod donosim prema: Alain FINKIELKRAUT, Pametno srce. Čitanja, s fran. prev. Marija Bašić (Un cour intelligent, 2009), Zagreb, 2014, 153 (u navedenoj knjizi Finkielkraut donosi vlastita iščitavanja 9 klasičnih književnih djela, a ovaj je citat naveden u sklopu vrlo zanimljivog eseja o Conradovu romanu »Lord Jim«).
} 
nema mjesta, niti je to cilj ovoga rada. $U$ »Dnevniku korote « jedna posve konkretna smrt otvara vrata meditaciji o nezamjenjivosti druge osobe, pri čemu se nipošto ne misli samo i jedino na njezinu fizičku nenadomjestivost, već prije na bitnu, supstancijalnu nenadomjestivost; čak ako je to moguće izraziti sintagmom o »nedostajanju nečije duše«, u strogo laičkom smislu, koji isključuje svaku religioznu i metafizičku primisao primarno se usredotočujući na neponovljivost osobe. Derrida, naprotiv, nudi drukčiju perspektivu.

Derrida je, kao što je već istaknuto, tijekom svojeg života ispisao popriličnu zbirku oproštajnih razmišljanja potaknutih odlaskom raznih velikih ličnosti (kao što su npr. Michel Foucault, Louis Althusser ili Emmanuel Levinas). Nužno je, dakle, još jednom primijetiti da je njegov susret sa smrtnošću i gubitkom izazvan odlaskom ljudi s kojima ga ne vezuje emocionalni odnos istog intenziteta kao što je to bio onaj koji je Barthesa vezivao uz njegovu majku. Među ostalima, posljednji pozdrav Derrida je uputio i samome Barthesu. Nije stoga naodmet vidjeti što je jedan velikan izrekao nad otvorenom rakom drugoga.

Početak Derridine refleksije već nagovješćuje duh kojim će se kretati njegova refleksija, te anticipira specifičnosti njegove »žalobničke misli« u njezinoj cjelovitosti. On bi, naime, želio posvetiti svoje misli njemu (Barthesu), doslovce ih dati, predati njemu, ali je pri tome svjestan da ga one uopće neće dotaći, dotaknuti s one druge strane koprene bitka iza koje je iščeznuo njegov lik. ${ }^{29}$ Logično pitanje koje se nameće iz te i takve Derridine želje jest: Kome onda uopće idu misli Preživjeloga, kojemu je dopalo nešto reći o pokojniku? Kamo odlaze? No, to ipak nije presudno pitanje Derridina korotničkog opusa, unatoč svojoj filozofskoj primamljivosti koja proizlazi iz načelne nerješivosti. Pa ipak, to ne znači da Derrida neće naznačiti svoj odgovor na njega. Naime, želja da se Drugome dadu, predaju misli upravo je vrlo otvoreno naznačen imperativ nastavljanja dijaloga. Dijaloga s Tišinom, sa zidom Šutnje koji Govornika dijeli od Drugoga. Nije pogrešno reći da će Derrida taj isti imperativ možda najljepše i najčistije artikulirati u svojem oproštaju s Gadamerom, koji je ne samo kronološki posljednja njegova eulogija, već i možda najsavršeniji kompendij njegova promišljanja o smrti, boli i gubitku.

Dobar dio Derridina »zbogom « upućenog Barthesu nesumnjivo bi bio veoma značajan filozofskim arheolozima, tj. povjesničarima filozofije, te poststrukturalistički nastrojenim kritičarima koji bi željeli ispitati međusobne odnose dvojice velikih umova i preplitanja njihovih ideja, te određena mjesta unutar njihova opusa. Derrida tako dobar dio svojeg teksta o Barthesu ${ }^{30}$ posvećuje

\footnotetext{
${ }^{29}$ Usp. Derrida, The Work of Mourning..., 35. Inače je to misao koju Derrida opsesivno varira kroz cjelinu svojeg korotničkog opusa. Motivi »dohvaćanja« i »pogleda« na Drugoga, nakon što je on fizički iščeznuo kao takvi, utkani su u temelje Derridina žalovanja.

${ }^{30}$ Usp. Roland Barthes (1915-1980). The Deaths of Roland Barthes, u: Derrida, The Work of Mourning..., 31-67.
} 
analizi njegovih knjiga »Writing Degree Zero« $\mathrm{i} »$ Camera Lucida«; ${ }^{31}$ znakovito odabranima, budući da je riječ o prvom i posljednjem Barthesovu djelu. ${ }^{32}$

Ipak, kad je u pitanju »Svijetla komora«, jedan bi segment mogao biti poprilično značajan za naše daljnje promišljanje i ucrtavanje još jedne poveznice između dvojice glavnih protagonista ovog teksta, a vezan je uz našu temu. Naime, znakovito je da je »Svijetla komora « također (djelomično) potaknuta smrću Barthesove majke i, za razliku od »Dnevnika korote«, ona se našla u završenom, a ne fragmentarnom obliku pred čitateljima. »Svijetla komora«, kao meditacija o fotografiji kao takvoj uključuje i jedan izrazito osoban, gotovo autobiografski moment, budući da, uz promišljanje o fotografijama raznih poznatih umjetnika, uključuje i razmišljanje o fotografiji Barthesove majke.

Meditacija o fotografiji, o tom ovjekovječenom trenutku, djeliću velikog mozaika koji u cjelini predstavlja vrijeme nečijeg života, implicira pomalo jezovit zaključak kojega Derrida ne propušta istaknuti u svojem tekstu. Ta strahota, uistinu ono jezivo kod svake fotografije jest ni manje, ni više nego - "povratak mrtvih «. ${ }^{33}$ Posve je prirodno da će svaka osoba ikada fotografirana, jednom biti mrtva. Taj blijedi odsjaj, ta sjena Drugoga; manja i ontološki beznačajnija od bilo kakve sablasti ili utvare koju čovjek sebi može dočarati uz pomoć vlastite mašte, ipak je nekakva avetinjska prisutnost Drugoga koja je Preživjelome nesumnjivo na svoj način značajna. Nešto poput odjeka s drugog svijeta, stišanog uzvika dozivanja koji se još uvijek, ma koliko razlomljeno i prigušeno, razliježe hodnicima vremena po kojima tražimo one koji više nisu s nama. Čak i više od toga, svaka je fotografija na svoj način svojevrsno obećanje smrti. Jer ono što neizostavno slijedi iz pogleda na nečije lice, čak i ukoliko je fotografirana osoba živa, jest snažna i otrježnjujuća spoznaja: Ova će osoba jednom umrijeti!

Nemoguće je da ove spoznaje ne pobude i drugu misao, u našem promišljanju puno značajniju. A što je sa slikom Drugoga utisnutom u sjećanje, u intelekt Preživjeloga? Zasigurno je istina da mehanička priroda fotografije na svoj način implicira hladnu, otuđenu i u dubini poprilično strahotnu impresiju, isto kao što površinski može izazvati čeznutljivu nostalgiju. Međutim, kad je riječ o slici koja počiva u duhu osobe, ne dobivamo li onda posve očitu suprotnost koja jednostavno iz temelja preokreće proganjajući nemir fotografije u nešto posve drugo? Mjesto na kojem započinje dijalog. Mjesto na kojem drugi nastavlja postojati i nakon odlaska. Tako barem smatra Derrida.

I dalje razmišljajući o Barthesu, štoviše, imenujući ga, gotovo u tradiciji starozavjetnog mističnog značenja vlastitog osobnog imena, Derrida naglašava da to »dozivanje ne može postati poziv, obraćanje«, već se obraća »njemu u sebi,

\footnotetext{
${ }^{31}$ Roland BARTHES, Svijetla komora. Bilješka o fotografiji, s fran. prev. Željka Čorak, (La chambre claire. Note sur la photographie, 1980), Zagreb, 2003; na djelo se dalje u ovom radu referira pod tim naslovom.

${ }^{32}$ Riječ je o posljednjem djelu objavljenom za Barthesova života, 1980. godine.

${ }^{33}$ Usp. Derrida, The Work of Mourning..., 41.
} 
njemu u nama«. ${ }^{34}$ Nema sumnje, dijalog se mora nastaviti. Derrida ne želi ni čuti za to da bi dijalog bio prekinut odlaskom Drugoga, jer za njega,

»govoriti o drugome, ocrtati barem djelić njega ili pokušati ga interpretirati, uvreda je, ali s druge strane i dužnost, dužnost spram drugoga «. ${ }^{35}$

To je trenutak kada Drugi postaje etički obvezujući za mene. Trenutak kojim započinje moje nošenje Drugoga, koje će u posljednjem pozdravu Gadameru postati središnjom temom.

Paradoksalno, upravo je to predokus onog atlasovskog (odnosno atlantskog) arhetipa žalovanja, tako tipičnog za Derridu. Žalovanja koje ne zastaje pred ponorom smrti, već ga nastoji premostiti, a nasuprot Barthesovu sizifovskom pokušaju da se dotakne i ponovno proživi sva neponovljivost supstancije Drugoga. I upravo je to mjesto koje veoma izravno povezuje Derridu s još jednim čovjekom koji je za »svetost« i »neponovljivost« Drugoga i njegova Lica, unutar suvremene kontinentalne filozofije, značio vjerojatno isto što i apostol Pavao za rano kršćanstvo - Emmanuelom Levinasom. I nad njegovim je grobom Derrida govorio, otvoreno se naklonivši i smjerno i s puno topline priznavši svoj dug Levinasovoj misli. ${ }^{36}$

Već na samom početku svojega posljednjeg pozdrava Levinasu (naslovljenog upravo - »Adieu«), Derrida kaže da se »dugo vremena bojao toga trenutka kada će morati reći zbogom Levinasu «. ${ }^{37}$ Nije ovdje riječ samo o neumitnosti smrti, o onoj toliko puta spominjanoj tragediji dvojice prijatelja od kojih je jedan uvijek osuđen biti Nadživjeli, koju je upravo Derrida izrazio. Nagoviještena je ovdje i ona »krivnja preživjeloga«, koju Derrida otvoreno posuđuje upravo od Levinasa. Ne bi valjalo ovdje osobnu pozadinu Levinasa, kao preživjeloga iz Holokausta, miješati s filozofskim terminom »krivnje« u kontekstu u kojem se ta riječ ovdje koristi, protiv čega se i sam Levinas oštro bunio, iako su, dakako takve interpretacije neizbježne. Krivnja preživjeloga nije ovdje proganjajući glas savjesti, već upravo suprotno. Ona je povjerena odgovornost za Drugoga koju svatko od nas dobiva, a koja do izražaja u svojem najekstremnijem i rubnom obliku dolazi upravo u trenutku odlaska jednoga od dvojice. ${ }^{38}$ Dapače, upravo smrtnost Drugoga jest najvažniji preduvjet moje odgovornosti. Njegova krhkost, lomnost i nestalnost traže mene u potpunosti, moj angažman usmjeren prema njegovoj dubini.

I nad Levinasovim lijesom, Derrida će se, po tko zna koji puta, iznova pitati kome se uopće u takvom trenutku onaj koji govori može obraćati, kakvom se odgovoru valja nadati, te se dotičući prirodnosti kolebanja između toga da se govor o pokojniku (pa i s pokojnikom) proglasi besmislenim i jalovim i napusti,

\footnotetext{
${ }^{34}$ Derrida, The Work of Mourning..., 46.

${ }^{35}$ Isto, 55.

${ }^{36}$ Emmanuel Levinas (1906-1995). Adieu, u: Derrida, The Work of Mourning..., 197-209.

${ }^{37}$ Isto, 200.

${ }^{38}$ Usp. isto, 204.
} 
jer završava u šutnji ili da, pak, monolog prijeđe u dijalog, nastavljajući se dok god onaj drugi živi. To raskrižje, mjesto gdje se obavlja taj izbor je, kako on kaže, »točka gdje nas riječi iznevjere, jer svaki jezik koji će se vratiti natrag govorniku - nepristojan je« ${ }^{39}$

Međutim, drugi ima svoje ime. Drugoga možemo tim imenom zvati čak i kada on ne može odgovoriti, kad se ne može odazvati. I tu Derrida zaključuje: »Ako nam više ne odgovara, to je zato što odgovara $u$ nama, iz dubine naših srca, u nama, a opet ispred nas. ${ }^{40}$ A taj odgovor zvoni čak i u onome: Zbogom!, koje mu upućujemo.

Dana 14. kolovoza 2004., malo više od godinu dana nakon što je održao svoj posmrtni govor Gadameru, a koji je držao znajući da je i sam teško bolestan, Derrida daje svoj posljednji intervju novinaru Jeanu Birnbaumu, a koji je značajan ne samo kao svojevrstan testament, već ujedno i kao zaokruživanje dosad izloženih misli ostvareno životom, konkretnim egzistencijalnim činom u odnosu spram smrti. On će tako ustvrditi da »nikada nije naučio živjeti, jer učiti živjeti trebalo bi značiti učiti umrijeti, učiti uzeti u obzir, odnosno potpuno prihvatiti, posvemašnju smrtnost ${ }^{41}$ bez izlaza koji nude ideje poput spasenja, uskrsnuća ili iskupljenja. Učiti živjeti uz filozofiju, taj gotovo antički, posebice stoički ideal, nije Derrida sigurno izrazio slučajno upravo na ovaj način. Uklapa se njegova misao $\mathrm{u}$ bilancu novoprobuđenog interesa suvremenih filozofa za duhovne vježbe $u$ antičkoj filozofiji, pri čemu ne treba pojam duhovne vježbe uzimati u strogo kršćanskom smislu, koji je kronološki kasnije preuzeo izvorni obrazac duhovne vježbe od antičke filozofije. Revitalizaciji zanimanja za tu temu ponajviše je kumovao Pierre Hadot svojim studijama o navedenoj temi, a one su većeg odjeka doživjele primjerice i u Foucaultovu promišljanju. Govoreći o »vježbi za smrt«, upravo će Hadot zapisati da to znači:

»vježbati se umrijeti za svoju osobnost, za svoje strasti, da bismo stvari vidjeli u perspektivi univerzalnosti i objektivnosti. Očito, takva vježba pretpostavlja usredotočenost misli na samu sebe, meditacijski napor, unutarnji dijalog.« ${ }^{42}$

U već navedenom intervjuu, Derrida će pomalo obješenjački ustvrditi da on »ostaje neodgojiv kad je riječ o bilo kakvoj vrsti mudrosti; kako umrijeti ili kako živjeti?« «3 $\mathrm{Pa}$ ipak, teško je takvu tvrdnju uzeti ozbiljno. Dapače, Hadotu bi se moglo dodati Derridino uvođenje kategorije koju pridaje njegovu »unutarnjem dijalogu«, a to bi bio »dijalog s Drugim«. Unutarnji dijalog tako nije samo dijalog sa samim sobom, već on uključuje i drugu osobu. Najveći je Derridin paradoks možda upravo u tome što sam ispovijeda svoju »neodgojivost«, a gotovo sve

\footnotetext{
${ }^{39}$ Isto, 201.

${ }^{40}$ Isto, 209.

${ }^{41}$ Jacques DERRIDA, Learning to Live Finally. The Last Interview, Hoboken, 2007, 25.

${ }^{42}$ Pierre HADOT, Duhovne vježbe i antička filozofija, s fran. prev. Zlatko Wurzberg, (Exercices spirituels et philosophie antique, Pariz, 1981), Zagreb, 2013, 39.

${ }^{43}$ Derrida, Learning to Live Finally..., 25.
} 
što je napisao o žalovanju, smrti, gubitku, odlasku govori u prilog intenzivnog nastojanja i truda radi samodiscipliniranja, te odgajanja sebe upravo u duhu ovog Hadotova citata.

»Preživjeti u klasičnom smislu znači nastaviti živjeti, ali isto tako i živjeti nakon smrti «, ${ }^{44}$ reći će Derrida. Misao o suprotstavljanju prirodnoj zakonitosti smrti, neizbježna je. Nije nužan samo kontinuitet postojanja, već upravo suprotno, čak i ako će se kontinuitet prekinuti, ako će se u smrti dogoditi radikalan raskid s određenim stanjem bivstvovanja, to svejedno ne znači de facto točku. To da se nakon smrti živi u Drugima, na posve očit način, kroz trag koji smo ostavili u njima, kroz odgovornost koju oni preuzimaju za nas nakon našeg odlaska s pozornice ovoga svijeta - već je dostatno isticana u ovom radu. Iza svega toga živi samo otvorena želja da se svijet oko nas jasnije sagleda, da se o njemu uspije nešto istinito reći, da ga se uspije potpunije shvatiti, čak i pod svjetlom krajnje točke kao što je to smrt.

Čovjek je daleko od toga da se posveti samo i jedino estetičkom promatranju i promišljanju svoje egzistencije, međutim, činjenica je da se čak i naizgled najbesmisleniji čini njegova života prigibaju pred diktatom neke nadvremenske Ljepote koja nadilazi taj život i tako orkestrira njegovu egzistenciju u svojoj cjelovitosti. Pojednostavljeno rečeno, nismo mi dužni nositi Drugoga da bi naš svijet bio malo ljepši, nego je naš svijet ljepši upravo zato jer Drugi u nama ima svoj zaklon, svoje prebivalište, mjesto u kojemu nije mrtav, nego naprotiv, veoma živ i koje nastanjuje svim svojim posebnostima. A mjera svjetova koji počivaju u nama, beskrajna je - to je ta silna snaga naših atlasovskih pleća koja na sebi nose Drugoga. A Drugi je Svijet.

\section{Jacques Derrida $i$ žalovanje $u$ »vnovima«}

Upravo nas inzistiranje na dijalogu za kojim Barthes čezne usmjerava prema Derridi i onome što je on izrekao u čast preminuloga prijatelja Hansa-Georga Gadamera. Barthes naime posvuda oko sebe i u sebi zapaža i opisuje potrebu za dijalogom, ostajući kod njegove nemogućnosti, protiv svoje volje prisiljen na svojevrstan defetizam. Već je istaknuto da je Barthesov gubitak neusporedivo veći i emocionalno složeniji od Derridina, stoga se ne želi implicirati »napredak« u Derridinoj misli o žalovanju, kao što bi nužno moglo proizaći iz konstatacije da Barthes udara u zid, dok Derrida nudi alternativu. No, s druge strane, isto je tako nepobitna činjenica da se Derrida u svojoj eulogiji odbija pomiriti s mogućnošću nemogućnosti nastavljanja dijaloga nakon Gadamerove smrti. Kao što je jasno da subjektivna priroda Barthesova žalovanja njemu onemogućuje pristup koji će iskušati Derrida, s druge strane, emocionalna dis-

${ }^{44}$ Isto, 26. 
tanciranost upravo je Derridin najsnažniji adut u pokušaju nastavljanja dijaloga s preminulim Gadamerom. Ona mu omogućuje da svoje misli iznese i izrazi istovremeno odlučnom sabranošću, ali i sa svom obazrivošću i intenzitetom proživljavanja prijatelja preminuloga, koja ipak dijeli zajedničke crte s Barthesovim promišljanjem, a može se reći i s općeljudskim iskustvom glede gubitka, žalovanja i boli prouzrokovane njime.

Emocionalna (čak i biološka, ako se tako može reći) distanca upućuje da se priroda osobnih gubitaka kojima su izvrgnuti Barthes i Derrida ne može izjednačiti, dok s druge strane refleksija obojice filozofa omogućuje da se dijalektički skoči u općenitu, univerzalnu prirodu iščeznuća Drugoga. Pojednostavljeno, to što Derrida promišlja smrt prijatelja, a ne majke, ne znači da on gubi manje i da manje oplakuje. Intenzitet boli s kojom se i Barthes i Derrida suočavaju nesumnjivo je različit, no pozadina - prekinut i nezavršen dijalog čiji su odlomci još živi u Preživjelome - nesumnjivo je ista.

Nasuprot Barthesovoj dubokoj tuzi i utučenosti (posve prirodnoj), kod Derride je prevladavajući sentiment melankolija, što je također posve razumljivo i smisleno. Tu melankoliju, s kojom se obraća slušateljstvu, Derrida će nazvati »bezvremenom«, izbjegavajući upotrijebiti pridjev »povijesna«, tvrdeći da ukoliko bi

»ona ipak odgovarala nekoj povijesti po nekom događaju koji je još uvijek teško razabrati, bilo bi to posebno, intimno, gotovo osobno, tajno i još uvijek u skrovitosti ${ }^{45}$

Govor o gubitku, o onome koga više nema, o boli prouzrokovanoj njegovim odlaskom nikada nije glasan; on je samo šapat. On je vezan uz našu najintimniju nutrinu, tiho i mirno mjesto gdje s njime raspravljamo i živimo poistovjećujući ga na neki način sa sobom.

Smrt je najradikalnija pojava koja karakterizira tu melankoliju, ona je pečati i postavlja svojevrsnu točku. Derrida naznačuje put kojim će krenuti tvrdnjom da unutarnjem monologu nužno mora prethoditi unutarnji dijalog. ${ }^{46}$ Misao koja se pretpostavlja i melankoliji i dijalogu o kakvom Derrida želi govoriti jest sljedeća:

»(...) ta je melankolija počivala na tužnoj i preplavljujućoj izvjesnosti: jednoga dana smrt će nas morati rastaviti. Zakon je to neumoljiv i sudbinski: jedan će od dvojice prijatelja doživjeti smrt onog drugog. « ${ }^{47}$

Iznova se, dakle, ponavlja i varira motiv »krivnje preživjelog «, odnosno težine »nadživjelosti« koja se spušta na njegova pleća. Bilo da je riječ o gubitku majke, prijatelja ili pak o »simptomu preživjelosti« u kontekstu Holokausta, gdje je ova sintagma također izrazito česta i mnogi su veliki mislioci na njoj sazdali

\footnotetext{
${ }^{45}$ Derrida, Ovnovi..., 7.

${ }^{46}$ Usp. isto, 16.

${ }^{47}$ Isto, 16-17.
} 
svoju misao (navedimo samo Viktora Frankla i Emmanuela Levinasa). Međutim, za Derridu sve ne prestaje činjenicom da je jedan preživio. Ta stvarnost ne čini Preživjeloga ni ukletim ni krivim, naprotiv - ona ga čini odgovornim. Stoga i kaže:

»Dijalog se nesumnjivo nastavlja slijedeći svoj trag u nadživjelome. On vjeruje da u sebi čuva onog drugog, činio je to već za njegova života; odsad mu daje riječ u svojoj nutrini. ${ }^{48}$

Pa ipak, kob nadživjeloga jest samoća. Od te činjenice ne bježi ni Derrida. Nadživjeli je svjestan da je smrću Drugoga jedan svijet doživio svoj kraj. On se sam tako nalazi između svjetova. Među ostatcima svijeta kojeg više nema i nad kojim gleda zalazak sunca, drugom nogom stojeći u svijetu koji mu je preostao, nakon iščeznuća svijeta Drugoga. Njegova podijeljenost i rastrganost isprva djeluju kao poprište intenzivnog sukoba, međutim beskonačnost dijaloga u Derride nipošto ne podrazumijeva Nadživjeloga razdiranog, već Nadživjeloga koji poprima gotovo vitešku ulogu »nositelja Drugoga«, nositelja onoga koga više nema. Ili:

»Kada svijeta više nema, kada je na putu da ne bude više ovdje nego tamo, kada svijet više nije blizu, kada nije više ovdje nego tamo, kada nije više čak ni tamo, nego je otišao daleko, možda beskrajno nepristupačan, tada ja moram nositi tebe, tebe samog, tebe samog u meni ili na meni samome. ${ }^{49}$

Derridina logika je vrlo jasna. Ako smo »brodolomci« izvan smisla, osuđeni na pejzaž apsurda, s horizontom Bitka koji se ni ne nazire u daljini, a ti si nestao, otišao, nalaziš se s druge strane rečenice, iza točke koju je ondje silovito stavila Smrt, ja sam taj koji ima obvezu, dapače, koji tebe radi tebe samoga mora uzeti na leđa i pokušati svim silama donijeti do horizonta Bitka, ako ga uopće mogu nazrijeti u daljini. Tek s krajem mojeg svijeta, u kojem će istovremeno umrijeti i posljednji ostatak tvojeg - moja je zadaća završena. Tek tada mi možda možemo biti cjeloviti.

Potku svojeg izlaganja, cijelu ideju »nošenja« Derrida gradi na hermeneutičkoj i egzegetskoj analizi pjesme »Veliki užareni svod« Paula Celana 50 koja završava upravo znakovitim stihovima: »Die Welt ist fort, ich muss dich tragen / Svijet je otišao, moram te nositi«. Naposljetku, sljedeće Derridine riječi stoje kao summa summarum ideja iznesenih u »Ovnovima« su sljedeće:

»Nijedan svijet nas više ne može podupirati, služiti nam kao posrednik, kao tlo, kao zemlja, kao temelj ili kao alibi. Možda nema više ničega osim bezdane visine neba. Sam sam u svijetu, ondje gdje više nema svijeta. Ili još: sam sam

\footnotetext{
${ }^{48}$ Isto, 17.

${ }^{49}$ Isto, 58.

${ }^{50}$ Za vrlo detaljnu analizu Celanove pjesme u kontekstu Derridina izlaganja vidi: Daniel MIŠČIN, Zagonetni ovan Paula Celana između hermeneutike i dekonstrukcije, Obnovljeni život, 3 (2013) 311-322.
} 
u svijetu otkad tebi dugujem sebe, otkad ti visiš o meni, otkad nosim i moram preuzeti odgovornost kojoj moram odgovarati pred tobom za tebe, licem u lice, bez trećega, posrednika i zagovornika, bez zemaljskog tla ili tla svijeta. Ja sam sam s tobom, sam za tebe samog, mi smo sami: ovo je izjava i obvezivanje. ${ }^{51}$

Žalovati, dakle, za Derridu, u bitnome je »nositi« Drugoga u trenutku kada svijeta koji smo s njim izgradili - više nema.

\section{Zaključak}

Tretiranje dvojice ovakvih filozofskih veličina nesumnjivo bi zahtijevalo više prostora nego što ovakav rad može obuhvatiti. Posebice bi se u Barthesovu slučaju moglo posvetiti detaljnijoj analizi teksta, s puno više inzistiranja na nijansama nego što je učinjeno u ovom radu, a bez čega se, nažalost, svaka obrada doima donekle plošnom i jednodimenzionalnom. Ovdje se u Barthesa usredotočilo na osobnu dimenziju njegove korote i ovisno o njoj prikazalo egzistencijalnu žeđ za dijalogom koji više nije moguć, te »sizifovsku« prirodu njegove korote, u kontekstu u kojem ona nikad ne dolazi svojemu konačnom kraju, a ne uspijeva ni nadići samu sebe. Upravo tema dijaloga i Drugoga, koji je sastavni dio pojma žalovanja »onoga-kojega-više-nema«, iskorištena je za prijelaz prema Derridi i njegovoj misli, samo kako bi se naznačilo da korota ne mora nužno biti »sizifovska«, već može, ostajući na antičkom teritoriju, biti atlasovska, odnosno atlantska. ${ }^{52}$

Postoji opasnost da postmoderni duh, kao odraz istoimenog stanja, izvrgne cinizmu ovaj diskurs koji bi danas mogao zazvučati pomalo patetično, pa se upravo zato valja pozvati na Giannija Vattima, suvremenu prominentnu osobu filozofskoga promišljanja, i na njegovo djelo »Transparentno društvo«, meditaciji o postmoderni i postmodernom stanju. Govoreći uopćeno o estetičkim teorijama i poimanju lijepoga, Vattimo piše:

»Ljepota je ukras u tom smislu da joj je egzistencijalno značenje, interes kojem odgovara, proširenje svijeta života u procesu upućivanja na druge moguće svjetove života, koji, međutim, nisu samo imaginarni ili marginalni ili komplementarni stvarnom svijetu; već sačinjavaju, konstituiraju, u svojoj recipročnoj igri i kao njihov preostatak, takozvani stvarni svijet. ${ }^{53}$

\footnotetext{
${ }^{51}$ Jacques DERRIDA, Ovnovi. Neprekinuti dijalog: izmedu dvije vječnosti, pjesma, Zagreb, 2014, 58-59.

${ }^{52}$ Prema Atlasu, Titanu iz grčke mitologije koji se borio protiv Zeusa, pa za kaznu mora nositi nebeski svod. Pojam koristim prvenstveno zbog važnosti glagola »nositi« u Derride, dok i za Atlasa on ima osnovno značenje na kojemu se temelji cjelokupan njegov smisao u antičkoj mitologiji.

${ }^{53}$ Gianni VATTIMO, Transparentno društvo, s tal. prev. Nino Raspudić (La società trasparente, Milano, 1989), Zagreb, 2008, 94.
} 
Sastavljene od komadića drugih, tuđih tekstova i misli, uz bljeskove osobne obojenosti ili pak posve originalne - u konačnici, za meditacije dvojice velikih filozofa o smrti, žalovanju i prolaznosti, to sve postaje posve nebitno. Ono što ostaje jest svjedočanstvo o mogućnosti pronalaženja ljepote i beskraja mogućih svjetova koji proizlaze iz tuge i melankolije, smrti i ostavljenosti, tih graničnih iskustava koja također čine našu svakodnevicu, a s kojima se ne znamo nositi, upravo zbog njihove specifičnosti i tih istih granica koje nam postavljaju, podsjećajući nas na našu konačnost.

Matej Vidaković*

The Concept of Mourning in Roland Barthes and Jacques Derrida

Summary

This article depicts the concept of mourning as it is depicted in Roland Barthes' Mourning Diary and Jacques Derrida's "Rams: Uninterrupted Dialogue between Two Infinities, the Poem". Derrida's discourse is based on a lecture given as an obituary given to his friend, philosopher Hans-Georg Gadamer. The article incorporates Derrida's thoughts in this text in his broader reflections on loss and death, since those are some of the topics he kept returning to in his work. One of the objectives of this expanded view is to present these somewhat neglected areas of Barthes's and Derrida's opuses as elaborated in the primary texts. The other objective is to bring the following thesis forward: Derrida and Barthes represent two sides of the same coin, two different streams of thought about loss, mourning and the unrepeatability of the experience of the Other. Their ways of thinking about these topics can complement each other and be subsumed under two archetypes: Sisyphus and the Antlanteans.

Key words: mourning, death, loss, the Other, Sisyphus and the Antlanteans archetypes.

(na engl. prev. Dubravka Sertić)

\footnotetext{
* Matej Vidaković, philosophy and religious studies student at The Faculty of Philosophy of the Society of Jesus in Zagreb, Jordanovac 110, pp 169, HR-10001 Zagreb, Croatia, E-Mail: matej.0211@gmail.com.
} 